\title{
DEVELOPMENT OF INTERFACIAL STRUCTURE INA CONFINED AIR-WATER CAP-TURBULENT AND CHURN-TURBULENT FLOW
}

X. Sun, S. Kim, L. Cheng, and M. Ishil

(Purdue University)

5. G. Beus

(Bettis)

\section{NOTICE}

This report was prepared as an account of work sponsored by the United States Government. Neither the United States, nor the United States Department of Energy, nor any of their employees, nor any of their contractors, subcontractors, or their mployees, makes any warranty express or implied, of assumes any legalliablity or responsibily for the accuracy, completeness or usefulness of any Intormalion, apparatus, product or process disclesed, or represents that its use would not whinge privately owned rights. 


\section{DEVELOPMENT OF INTERFACIAL STRUCTURE IN A CONFINED AIR-WATER CAP. TURBULENT AND CHURN-TURBULENT FLOW}

\author{
Xiaodong Sun, Seungin Kim, Ling cheng, \\ Marnore Ishit \\ Thernal-Hydraulics and Reactor Safety Laboratory \\ School of Nuclear Engineering Purdue University \\ West Latayetie, IN 47907, USA \\ 'E-mal: shingecr purdue edu
}

\author{
Stephon G. Beus
}

\author{
Bettis Atomic Power Laboratory \\ Bechel Betts, Inc. \\ Post offec Box 79 \\ West Mimin, PA 151220070, USA
}

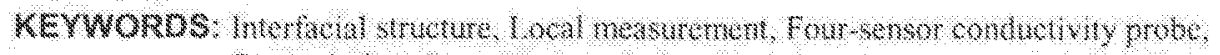
Cap tubulan How Chum-urbulen Hew

\begin{abstract}
The objective of the present work is to study and modul the

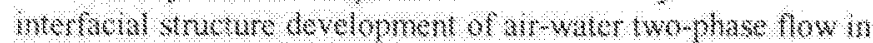
a confined tes seckom Experiments of th total of 9 fow conditons in cap-arbulent and chum-turtulent fow regmes

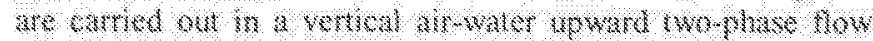

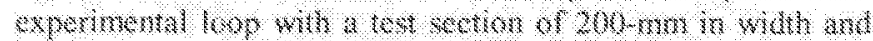
10-mm in wep. Miniahried four-sensor conductwity probes are bed to seasure lockl two-phase paraneters at thee Wherent elevarons for ach fow condition. The bubbles kaphured by the prokes at categorized into two groups in vew of the two-gromp intertacial area thaspon squblom. he.

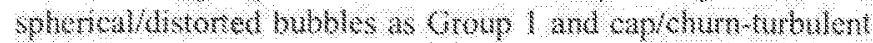
hubbles as Grop 2. Whe acqured parameters are timeaveragel lowl wid frebion, merheil velocty bubble number frequency. interfach area concentration, and bubble sauter mean dianeter for both groups of bubbles. Also, the lineaweraged and arow-rweraged data are presented and disoussed. The compansoss of these prameters at diferent devalioms demowstrate the deyeloprsere of interfactal structure along the How dhection das to bubble interactions.
\end{abstract}

\section{NTRODUCTION}

In grasligul rwephase how the wold fraction and bertachal aros concentraton charsoterie the geometris

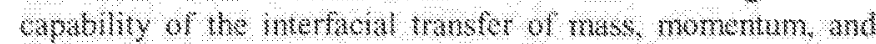

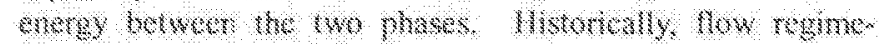

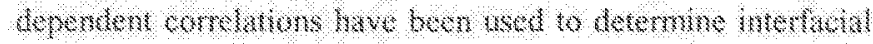

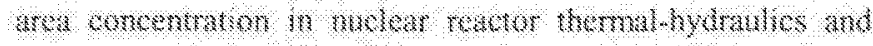
stery systen codes. However most of the how regime transition critera were dewoloped for state fully develancl fow, Thurefore, this correlation approach does now properly acconat for either the dynume rature of the change in the interfacial structure or the entrance effects of the fow $1 n$ wew

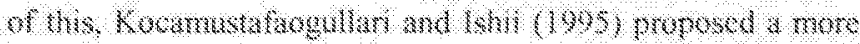

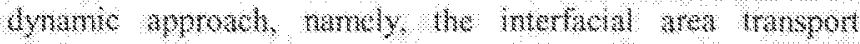
equation. By mechanisticaly modolng the major bubble colesence and disintegration whenomena. Wu st al (1998) and Kim et al $(2001 \mathrm{~b}$ ) developed the one-group interfacial ares transport chantion. whoh is applicable lo bubbly flow in conumction with the heoretical othons exprimental sudy bas

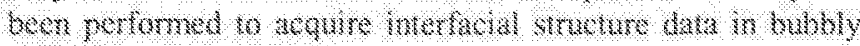
flow (Kimet a), 2001\%).

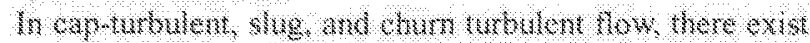

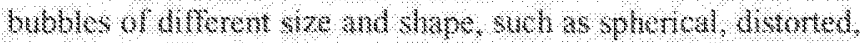

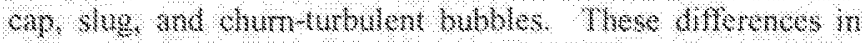
bubble kize and shape lead to subsiminal diferences in bubble transport phenomerna such as drag force, bubble meracton mechanisms, ete. In the one-group mertachal area trawspon equation, hese differences have not been accomnd for bue to its one-group nature (Wu of al, 1998 and Kin ef al, 2001 b). Therefore, in order to desenbe the interlacial structure developnent in a more generalized two phase how the onegroup transpor equaton nowds to be cxiondel to a two grows transport equation. Meamwhile, a rolable database is indispensablo wo ewalute he two-groun trangon equaton.

The presene shay is a conbmation of the prevous experimental sfors for bubbly How (Kim ef al, 200la). Extensive experiments hwe bers corred oul in the same

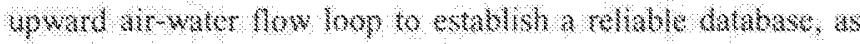
well as to gan a biter andorstanding of the menthol stnowne

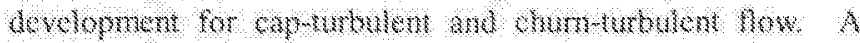
Haxhate in 9 flow conditions at captwbulent and chums. 


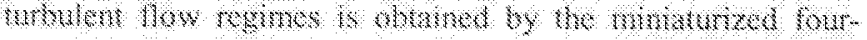

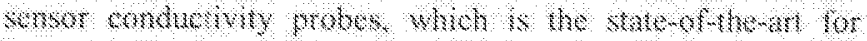

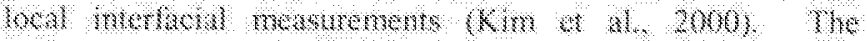

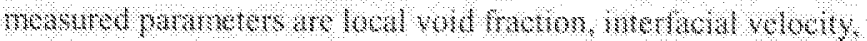

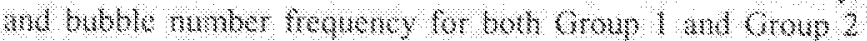

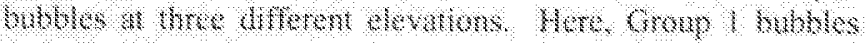

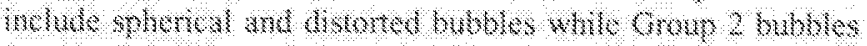

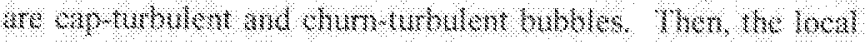

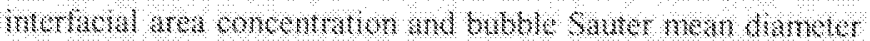

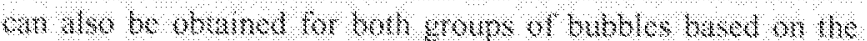

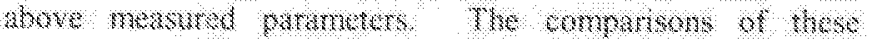

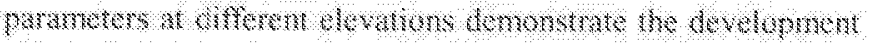

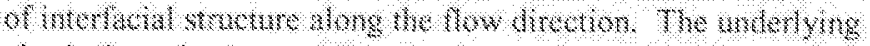

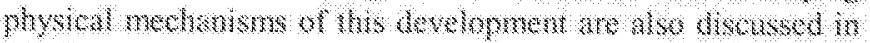
6em:?

\section{NOM ENCLATURE}

\begin{tabular}{|c|c|}
\hline क. & murlas a area concentromen $(1 \mathrm{~m})$ \\
\hline 11.ma: & max rmum diswored whble limit fro \\
\hline$l_{4}$ & 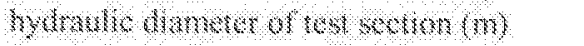 \\
\hline$O_{m}$ & Samkr man thmomer of bubbles (m) \\
\hline 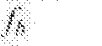 & 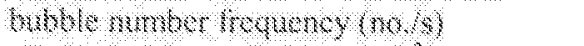 \\
\hline 8 & gravmanonal accelomon $(\mathrm{m} / \mathrm{s})$ \\
\hline \% & 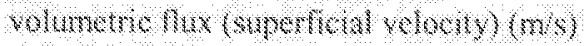 \\
\hline t & velowhy (mos) \\
\hline : & 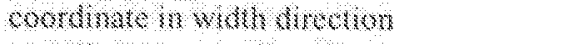 \\
\hline 8 & 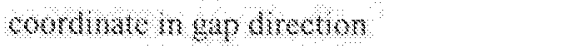 \\
\hline 8 & 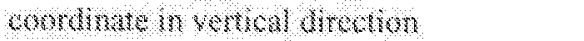 \\
\hline
\end{tabular}

\begin{tabular}{|c|c|c|}
\hline \multicolumn{3}{|c|}{ Crock syrowols } \\
\hline 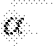 & Wond Twotmon & \\
\hline$\%$ & swhos tonswon (X/n) & \\
\hline Ko & 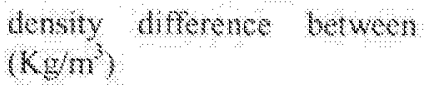 & wo plowes \\
\hline
\end{tabular}

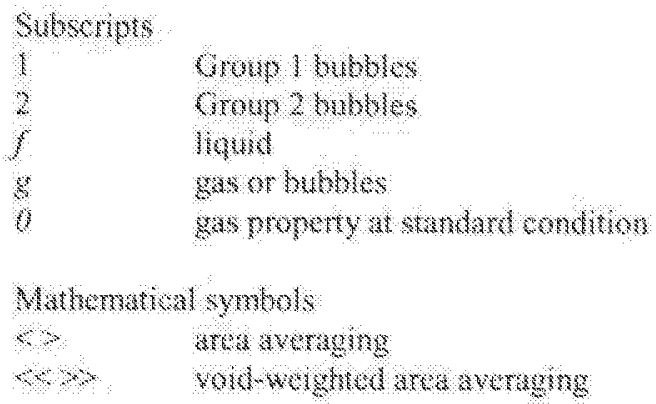

\section{CXPERUMWNAL FACILITY}

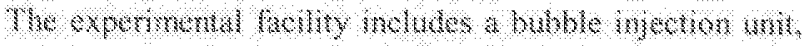

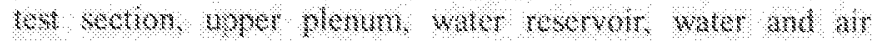

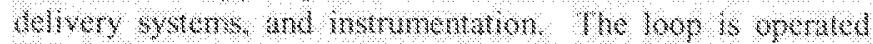
wher hmosplese pressure The demmeralized water is

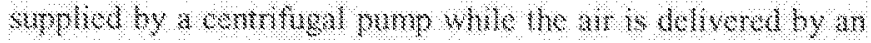

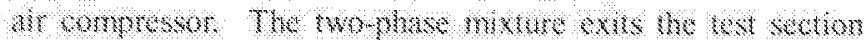
ane enters the upor flonm for semantion and the water and

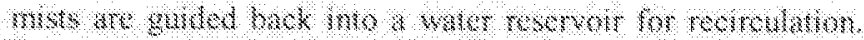

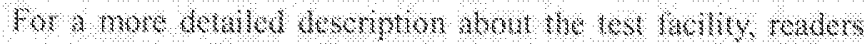

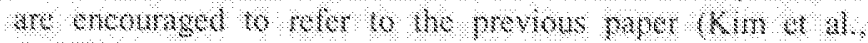
$210 \%$

The arowher wophase minture is gemorted ty a spotwly

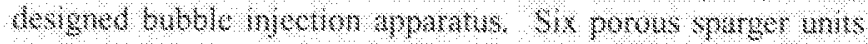

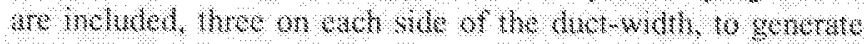

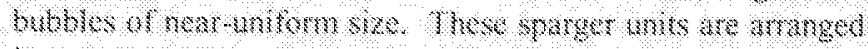

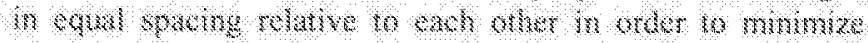

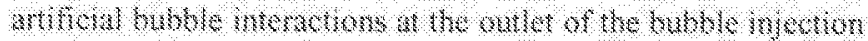

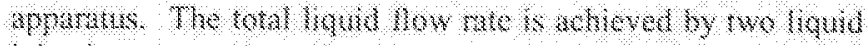
Wherous ane hwough the six somger whe of the buble

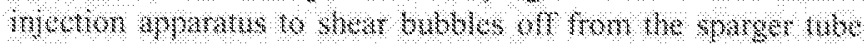

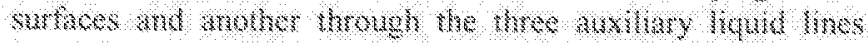
sworkd wh one she at he botwm of the buble mothom woratas:

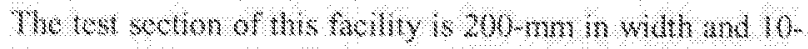

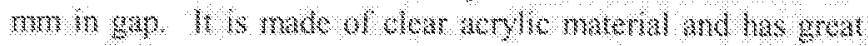

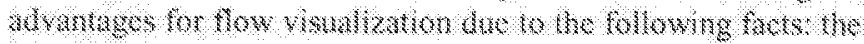
nown of the at bobhes is close to twothmonsional the

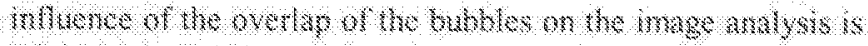
mommod, and the mage distortion due to chrature effect is

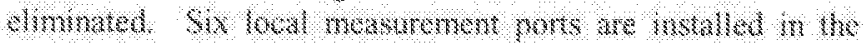

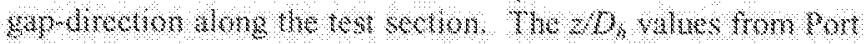

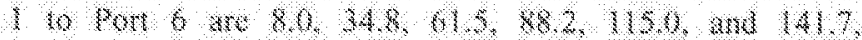

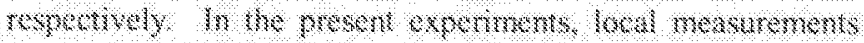
are promed a Por 2, Por 6 and Port 6.

\section{MEASUREMENT TECHNIOUE}

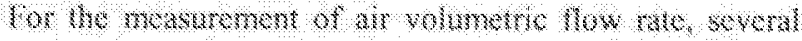

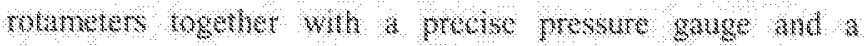

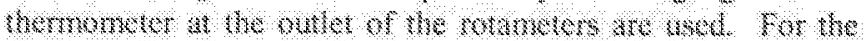

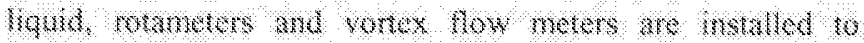

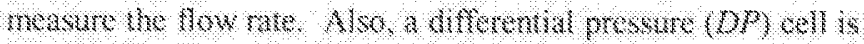

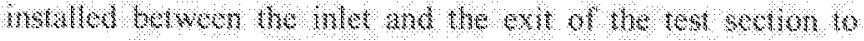
messure the presware stop in the lob sectom.

The conductiny prote frot proposed by Heal and

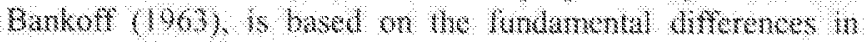

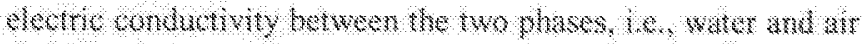

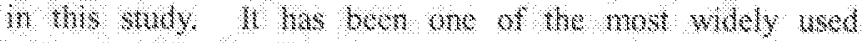
mormmonen wombues in gahloud hombare how

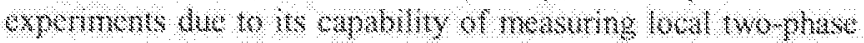

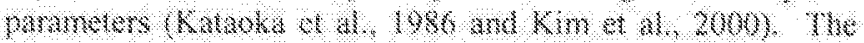

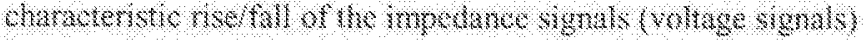

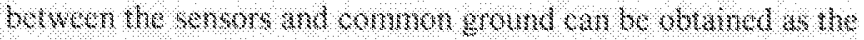
hobhes pas she brough the shosed the of the probe sensers.

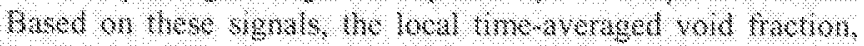
werwow weocly. and bubble number hequency on be

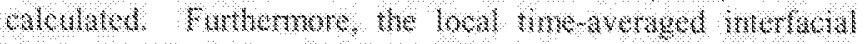
wea comonn arom com bo abmined.

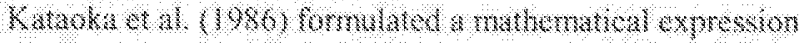

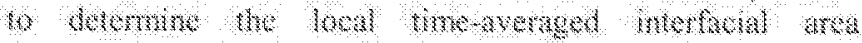




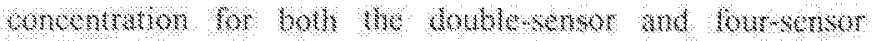

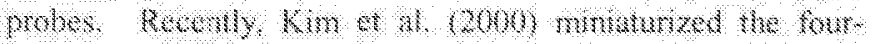

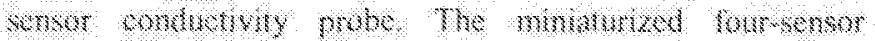
comduchnly mole conomsts of one common senwor. whoh is in

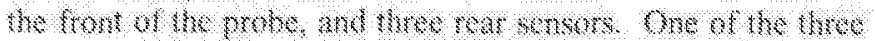

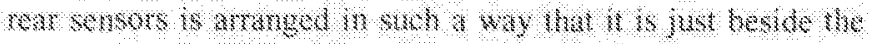

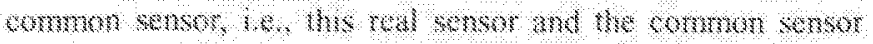

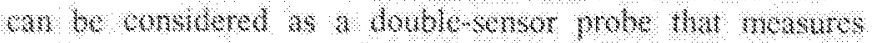

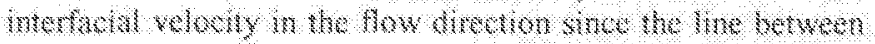

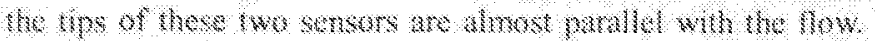

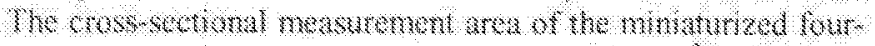

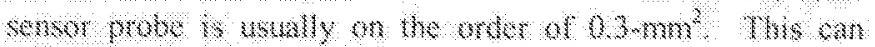

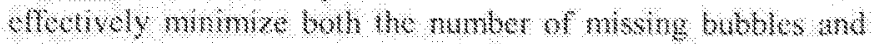

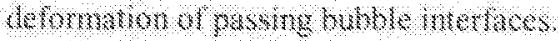

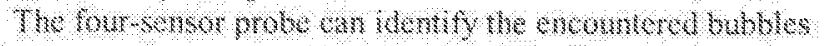

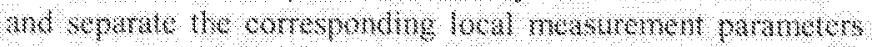
mo tho grouss basul on he buble chond lengh mformoton

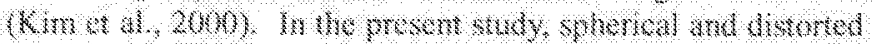

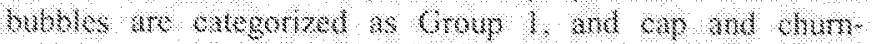

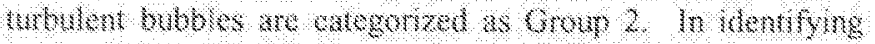

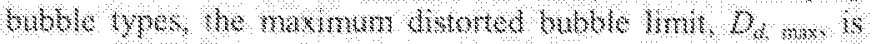

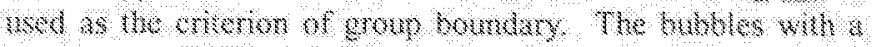

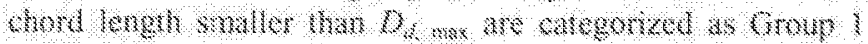

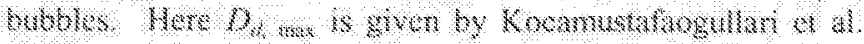
$(1984) 35$

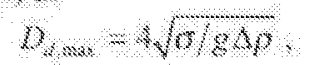

whoh is appowimatly $10 \mathrm{~mm}$ for armotes how wnder

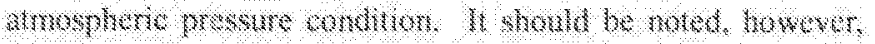

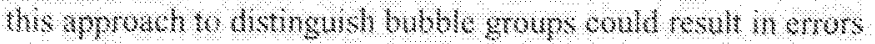

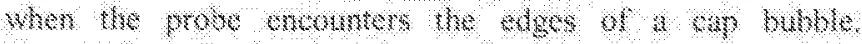

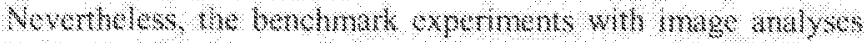

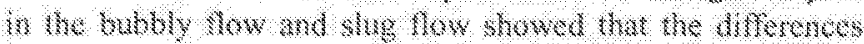

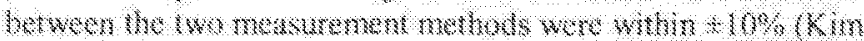
a. $2000 \%$

\section{EXPERWENTAL CONDTIONS}

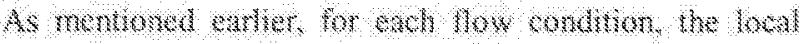

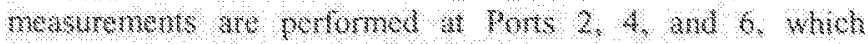

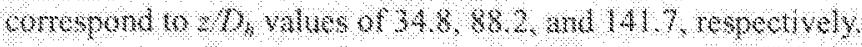

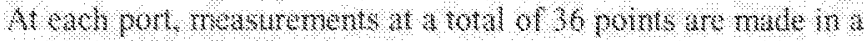

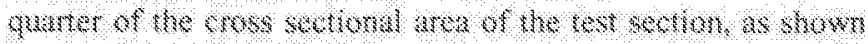
wi Fis. I. Spe dheck is kone to assme good wrmem of the

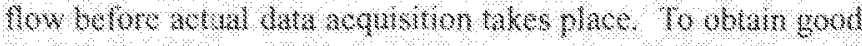

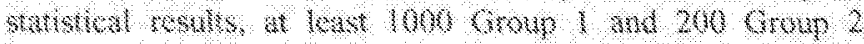

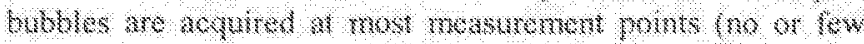

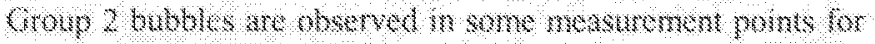

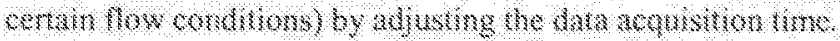

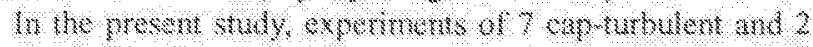

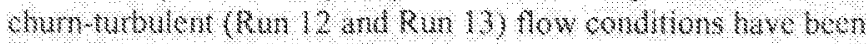

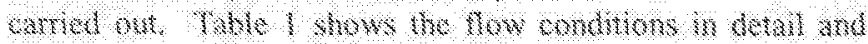

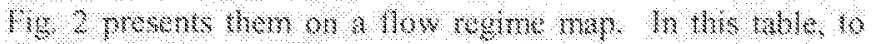

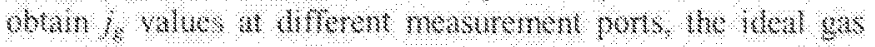

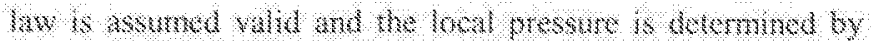

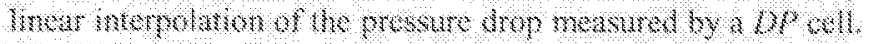

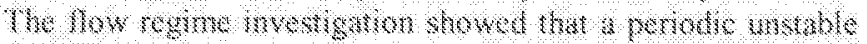

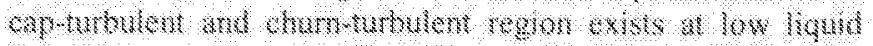

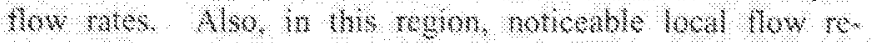

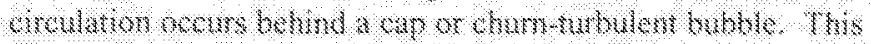

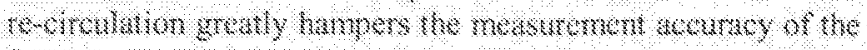

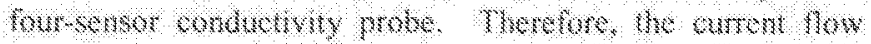

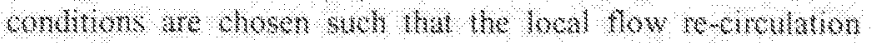
resom 4 anomed

11 showh the noted thet in the provous experments

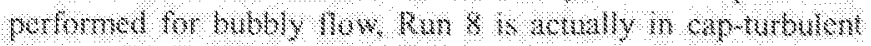

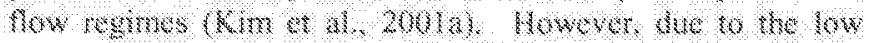

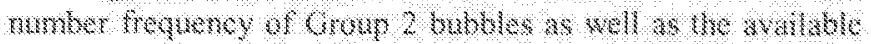

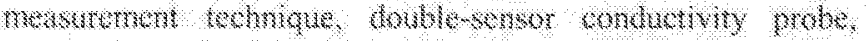

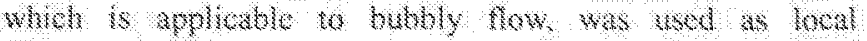
mstmmens. In the cumen andy a formsexsor ph be s used and the dak in the flow cond tron s reocerwed.

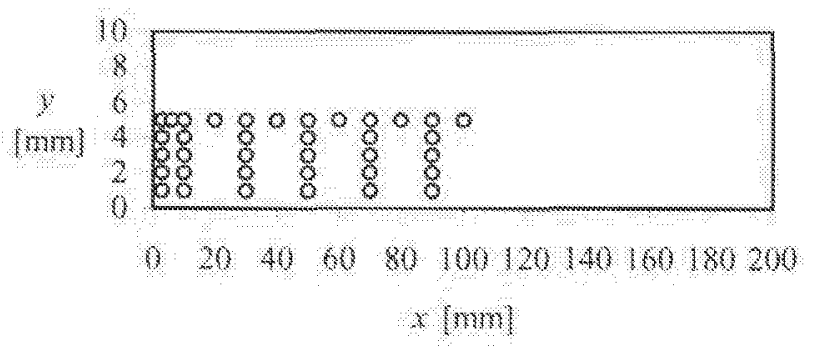

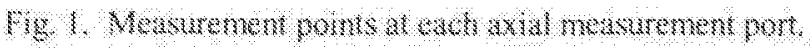

Table 1. Expenmenal kow sombrons:

\begin{tabular}{|c|c|c|c|c|c|}
\hline \multirow{2}{*}{ Exw No } & \multirow{2}{*}{$f,(\mathrm{~ms})$} & \multirow{2}{*}{$(\mathrm{g} / \mathrm{m} / \mathrm{l}$} & \multicolumn{3}{|c|}{$L 0001 / 4,(n / s)$} \\
\hline & & & Pror & Por 4 & Fort 6 \\
\hline 8 & 1.89 & $03 \%$ & $\$, 10$ & 0,32 & 0.36 \\
\hline 10 & 0,32 & 0.41 & 0.34 & 0.36 & 0,38 \\
\hline 11 & 0.95 & 047 & 0.31 & 0.40 & 043 \\
\hline 12 & 284 & 100 & 073 & 0.82 & 093 \\
\hline 13 & 284 & 201 & 143 & 1.61 & 134 \\
\hline 14 & 0,63 & 0.42 & 034 & $\$ 36$ & 0,30 \\
\hline 13 & 1.89 & 0.58 & 0.44 & 0.48 & 1,5 \\
\hline 16 & 126 & 0.66 & 052 & 0,36 & 0.61 \\
\hline 18 & $18 \%$ & 0.92 & 041 & 0.44 & 0.38 \\
\hline
\end{tabular}

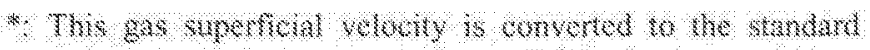

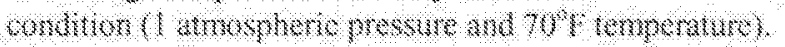




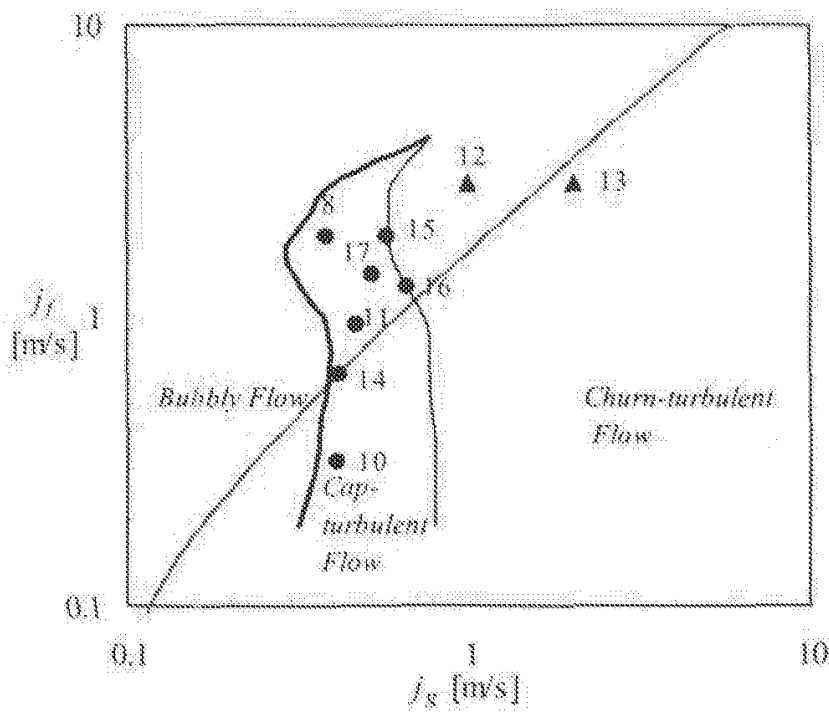

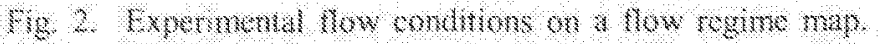

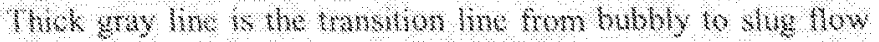

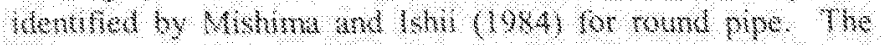

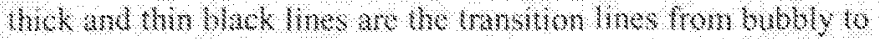

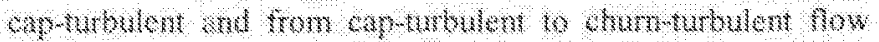

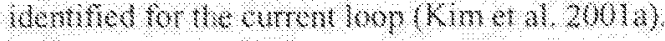

\section{EXPERIMENTAL RESULTS}

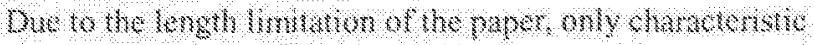

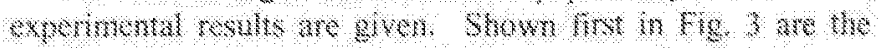

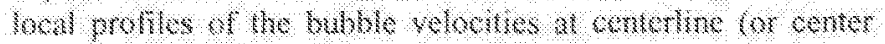

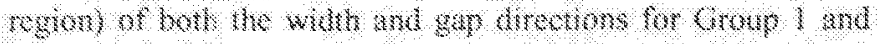

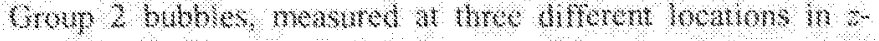

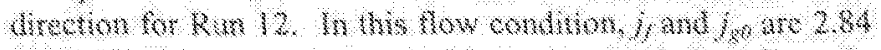

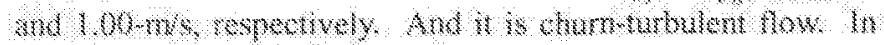

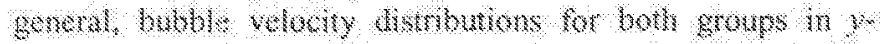

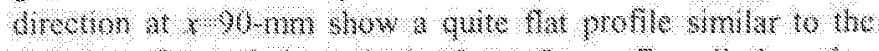

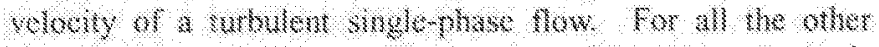

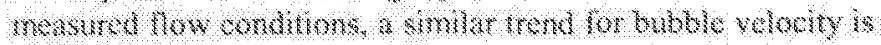
whervel lowever, of y 4 rom, which s very chos to the whll.

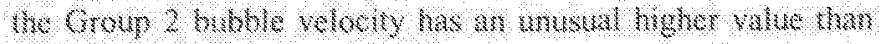

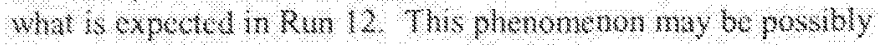

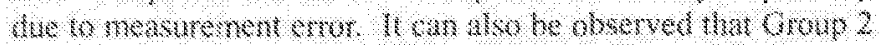

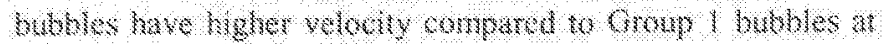

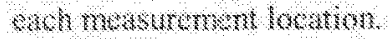

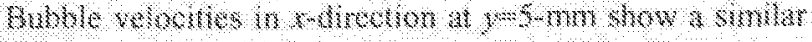

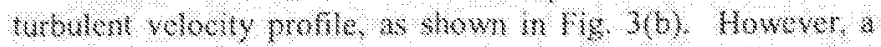

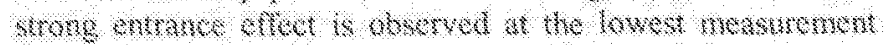

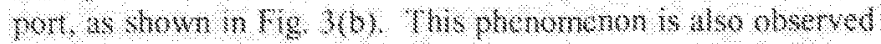

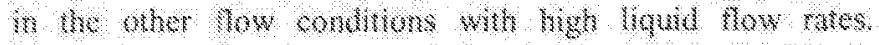

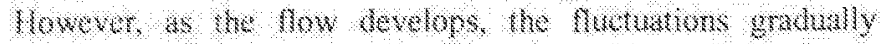

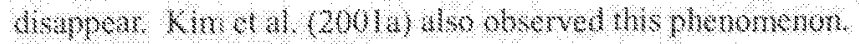

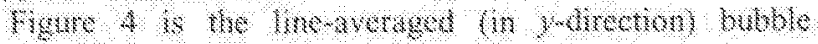

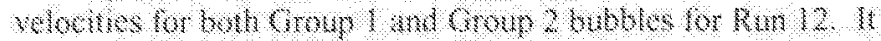

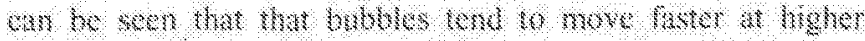

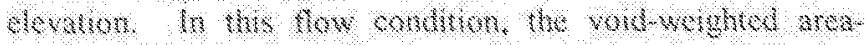

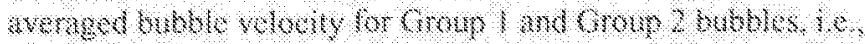

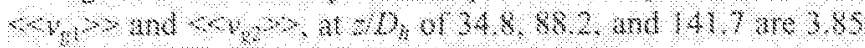

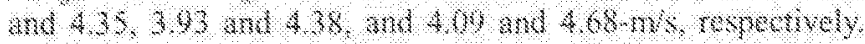

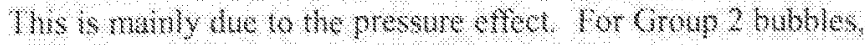

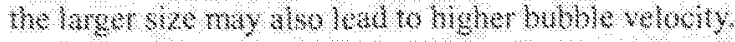

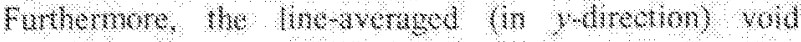

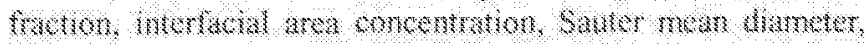

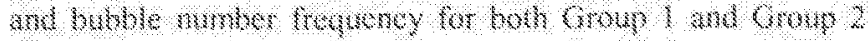

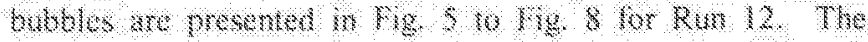

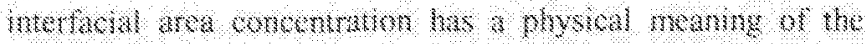

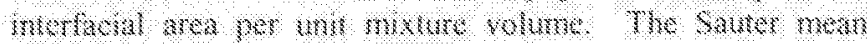
bianeber 16 dented as

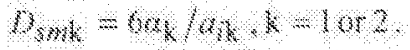

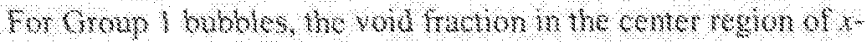

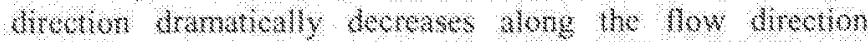

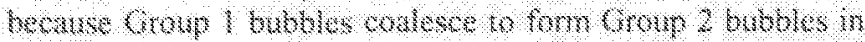

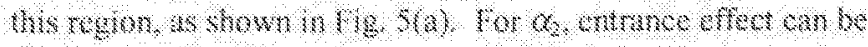

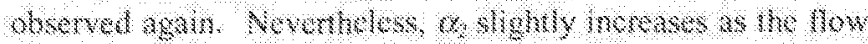

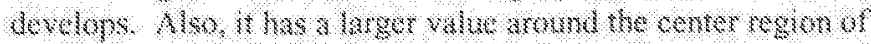

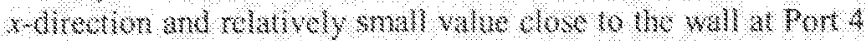

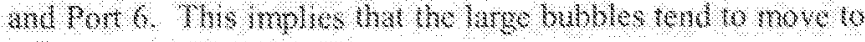
the wenter of the 108 sectrom.

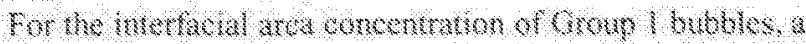

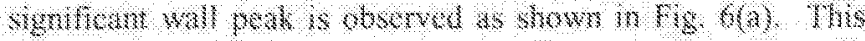

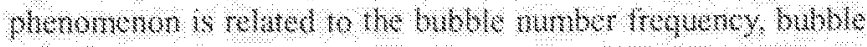
keloctly, and bublle aze. The samer mean dumeler of Group

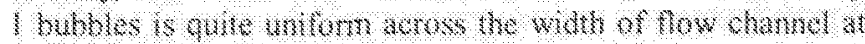

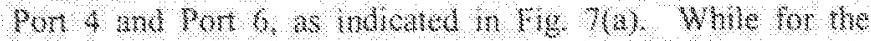

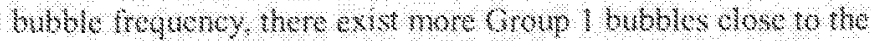

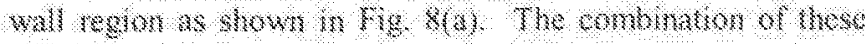

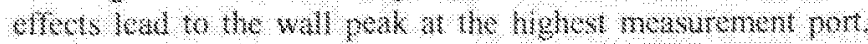
For cmor 2 wabls, as brow a smolm proble as $q$.

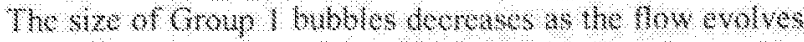

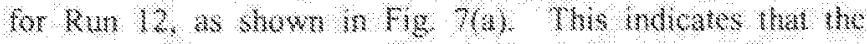

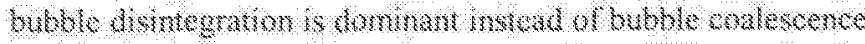
whe regon clow to the wall of a drecton. The can whe be

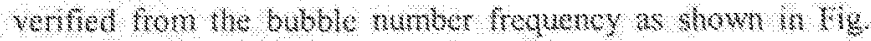
8(a). However whe cente region, Grow 2 bobles wighly

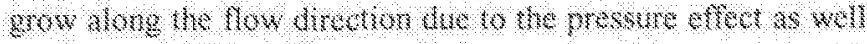

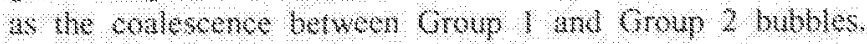

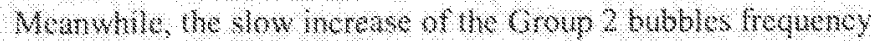
molotes the fommon of Grou 2 buboles from the

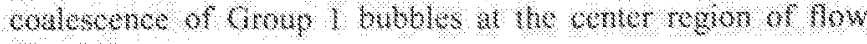
chame:

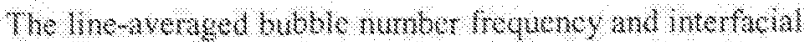

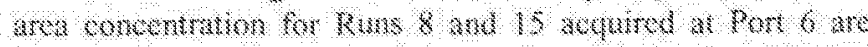

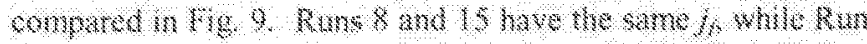

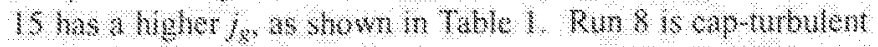

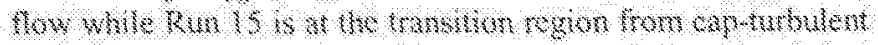
so shum whblent $10 \mathrm{k}$.

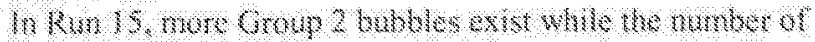

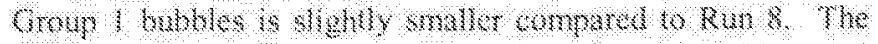




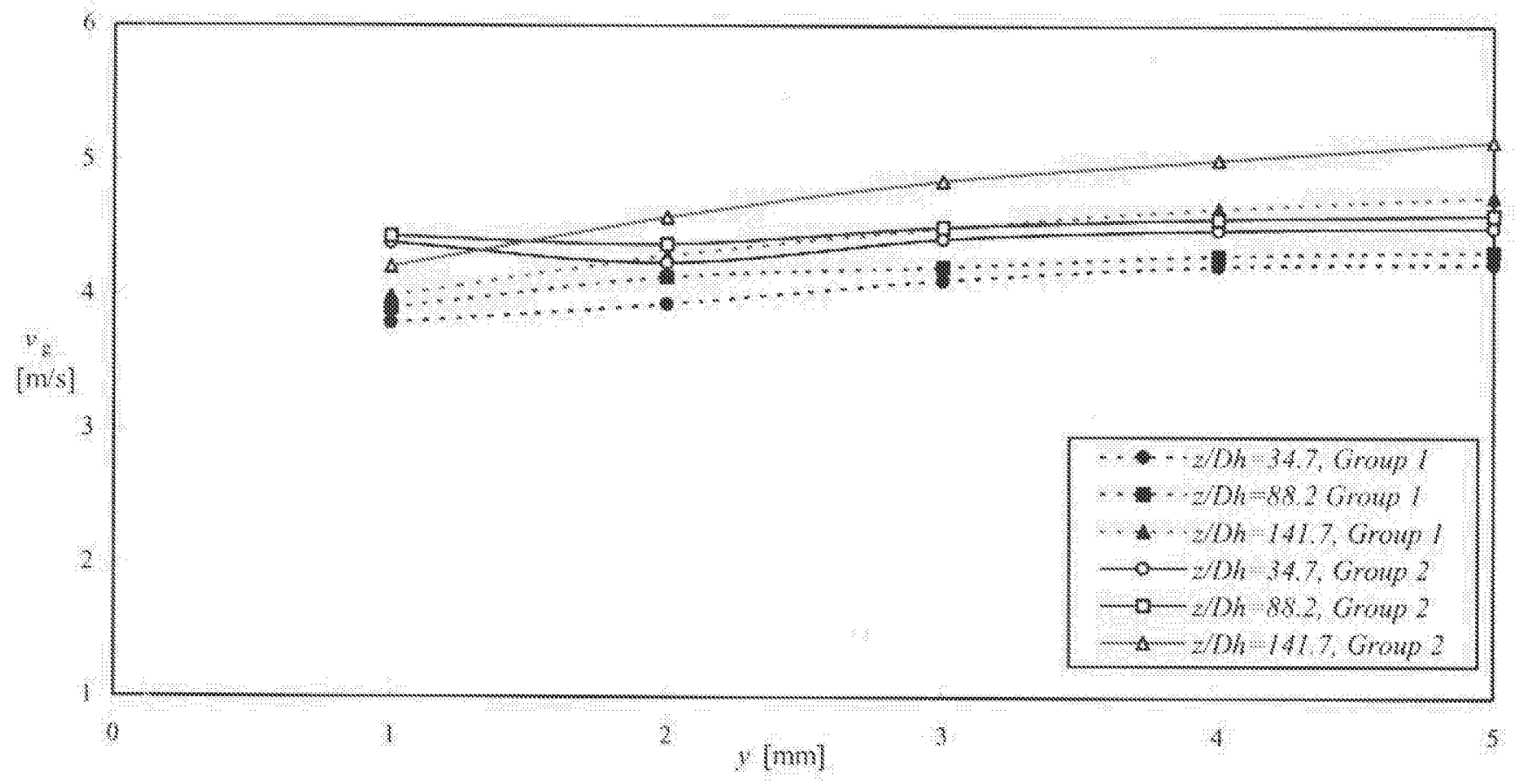

(a) Cerster region min widh diretion (690 mim)

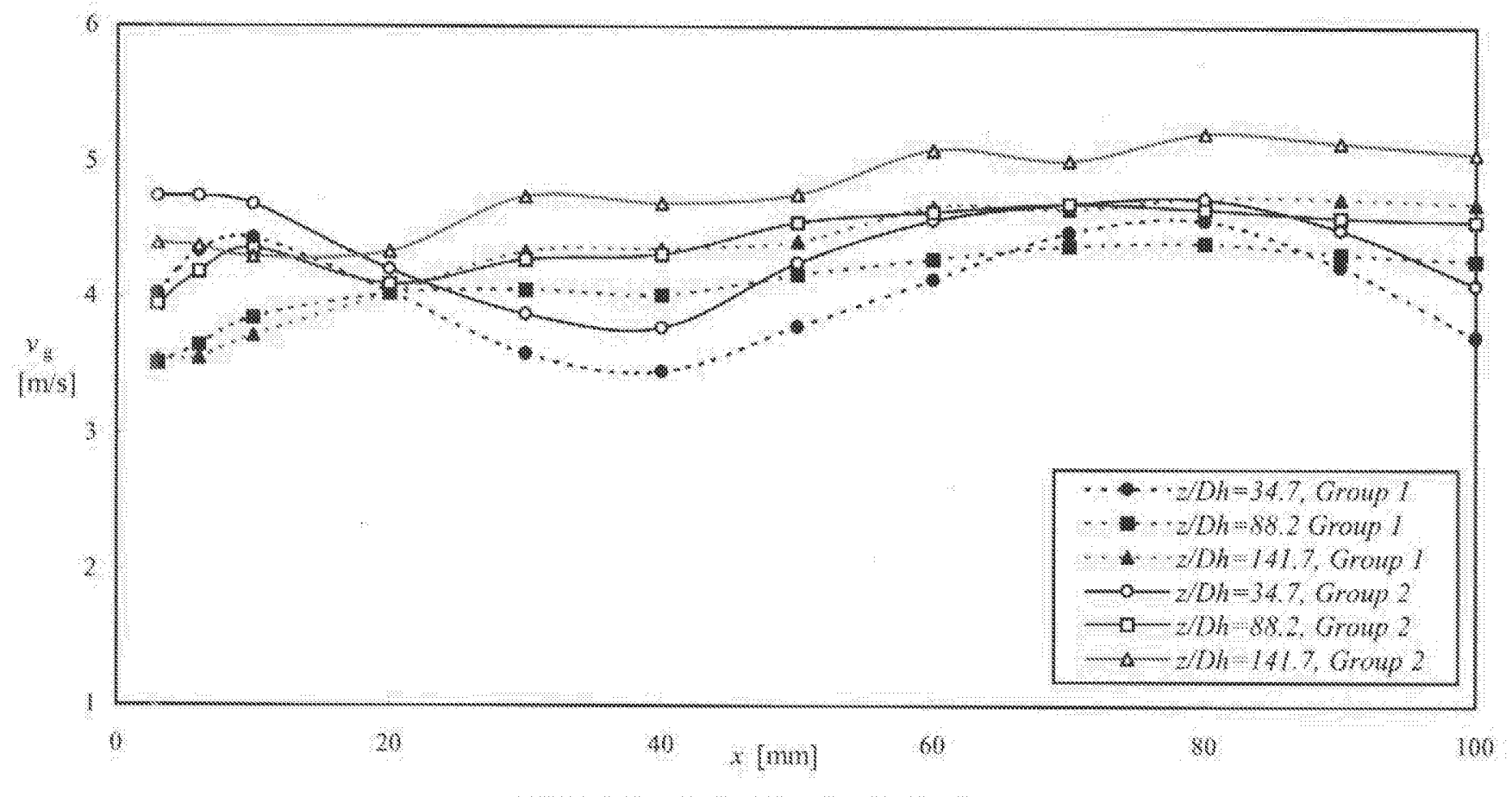

(b) Centerline in gap direwon $(1$ sesm

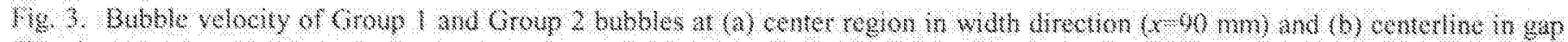

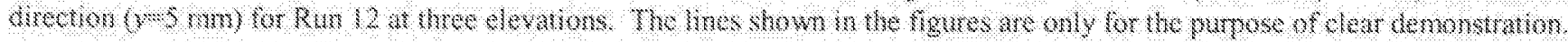




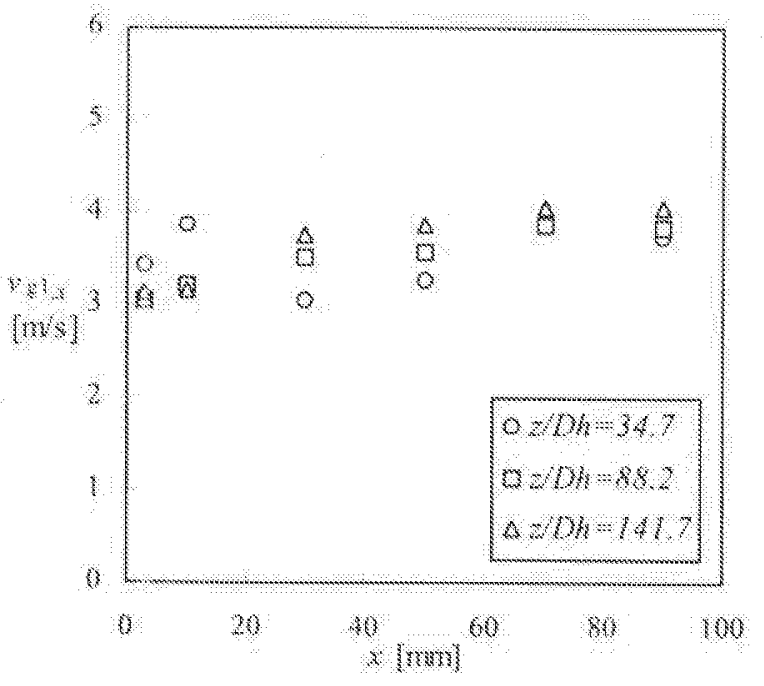

(4) Sroup 1 hithes

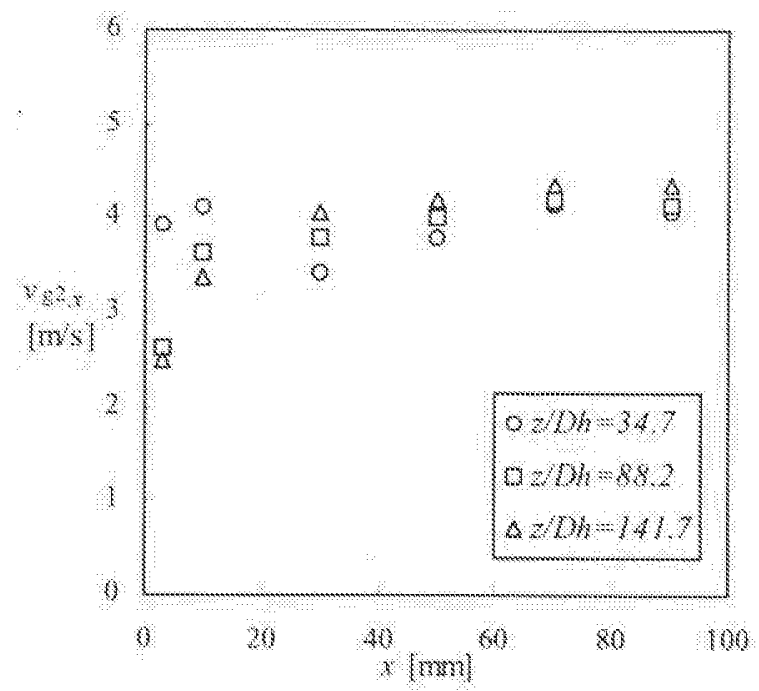

10 croug 2 lubbes

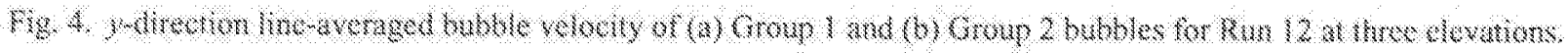

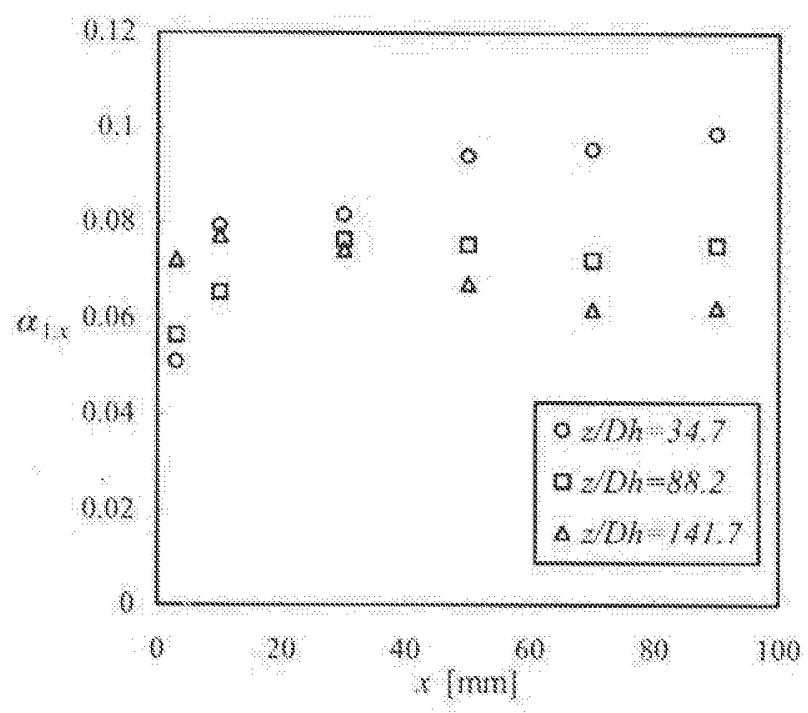

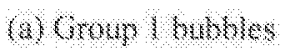

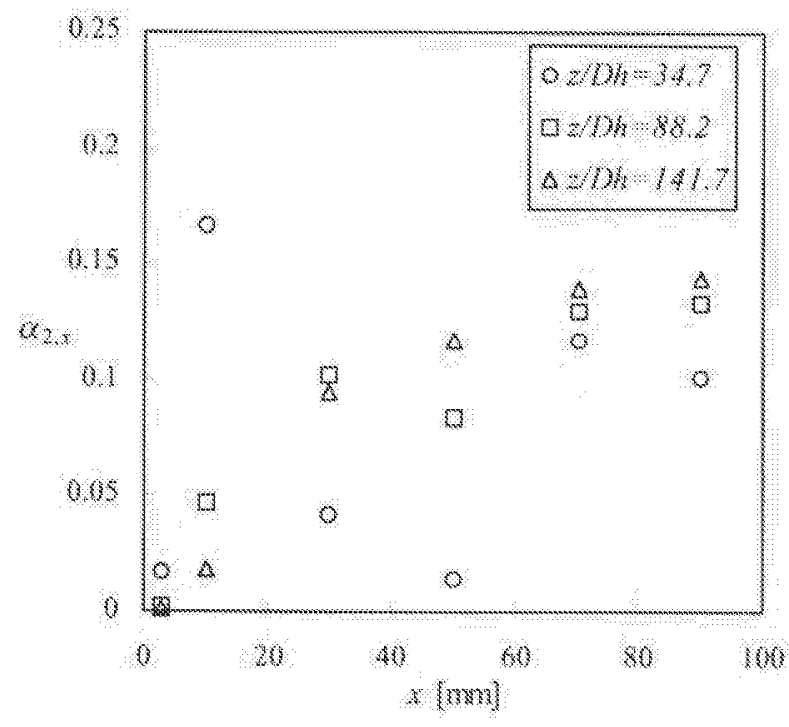

(1) Crap 2 bubses

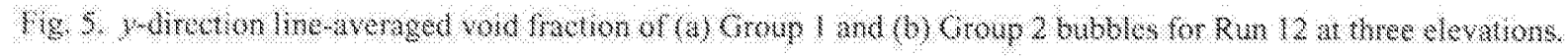




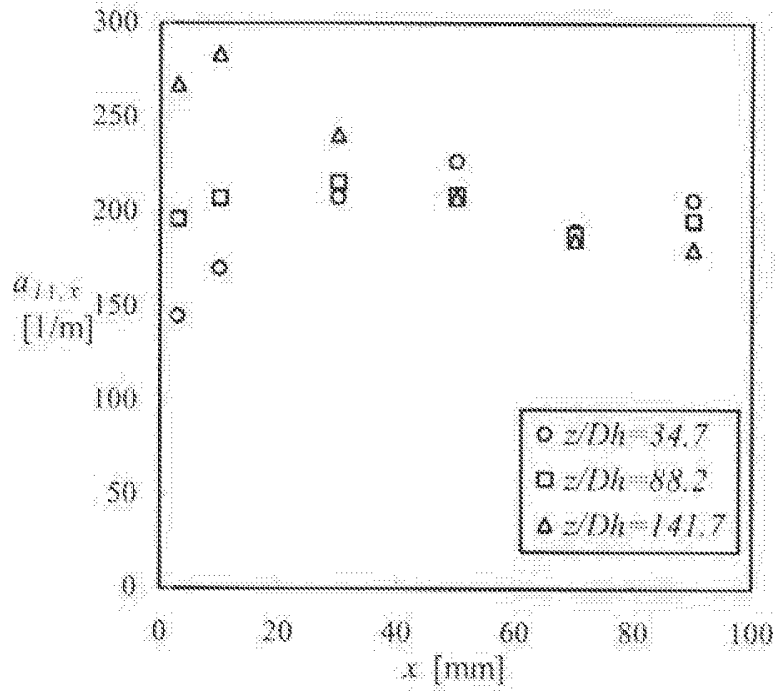

40 rom $)$ buboles

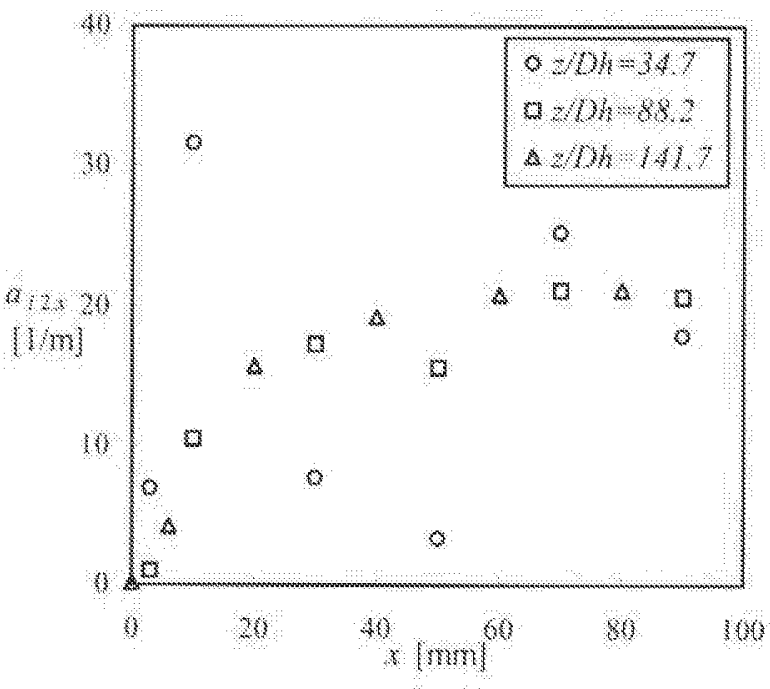

(6) Grom 2 matelos

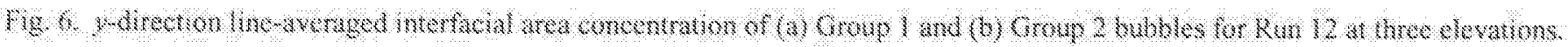

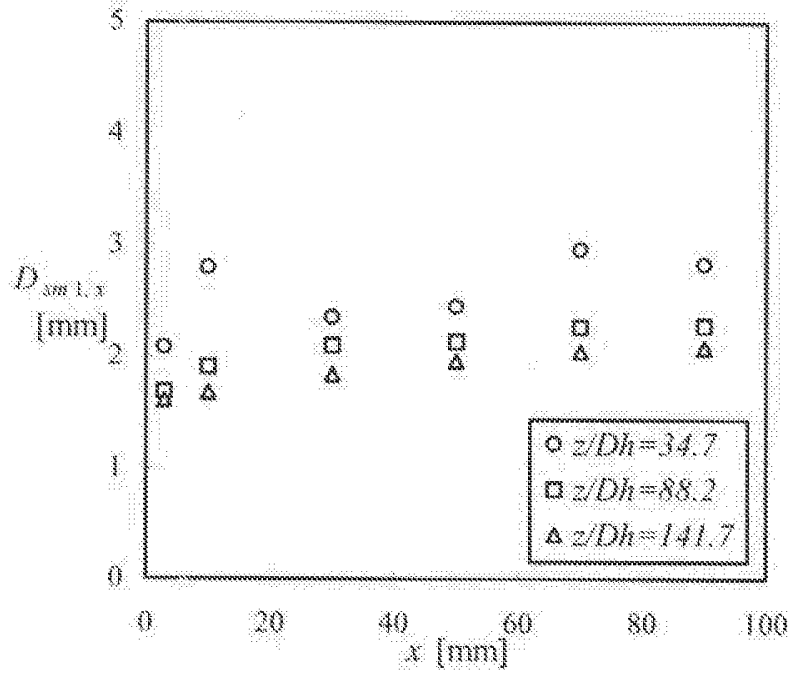

(a) crompl bublos

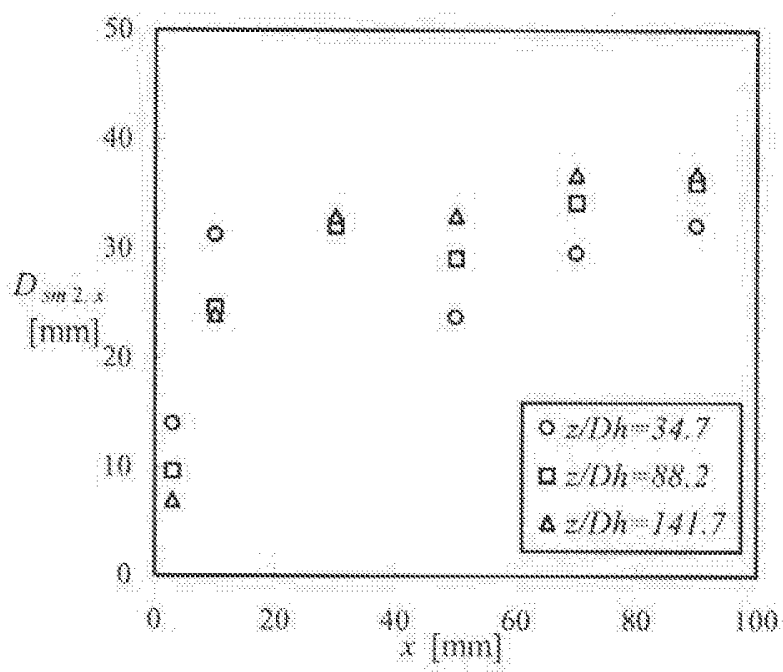

(6) Grm andks:

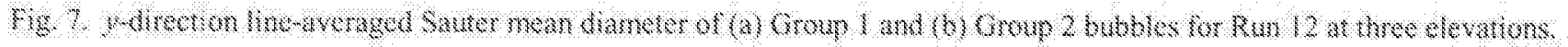



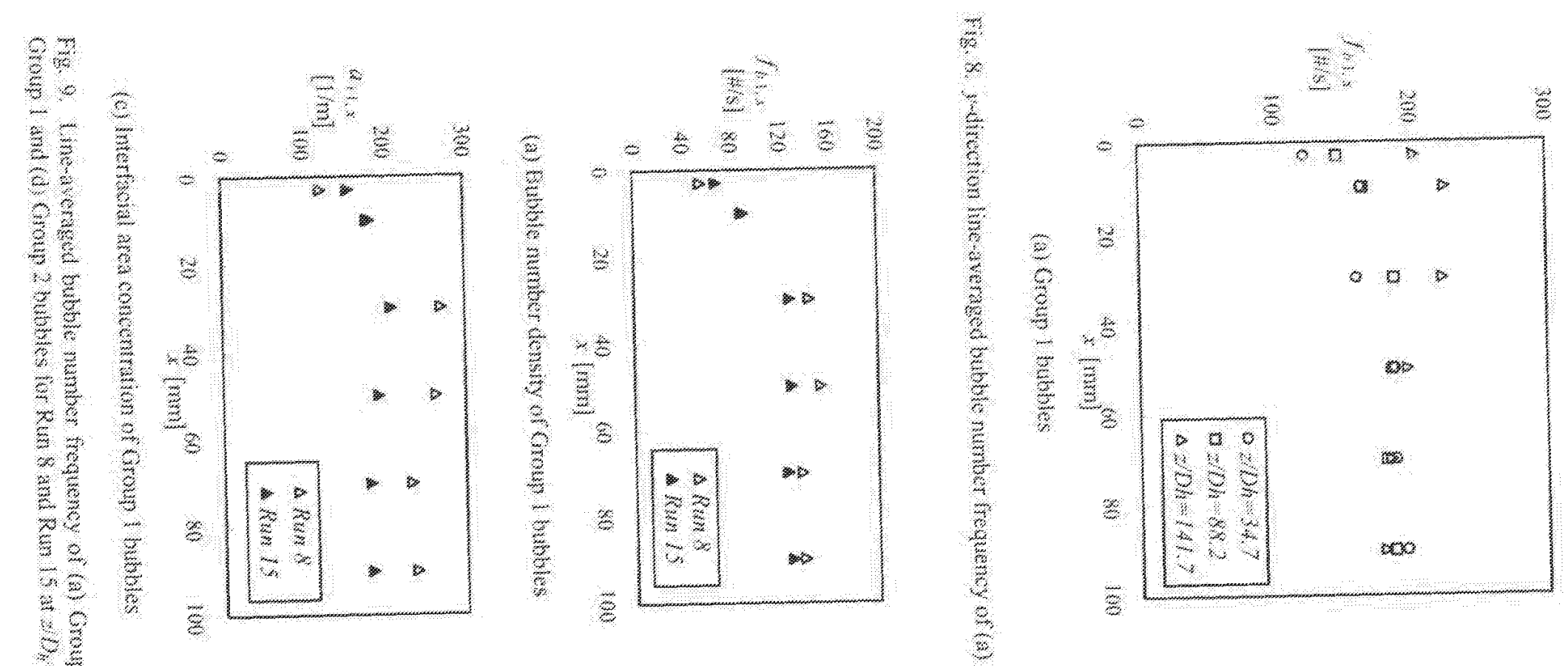

$\infty$
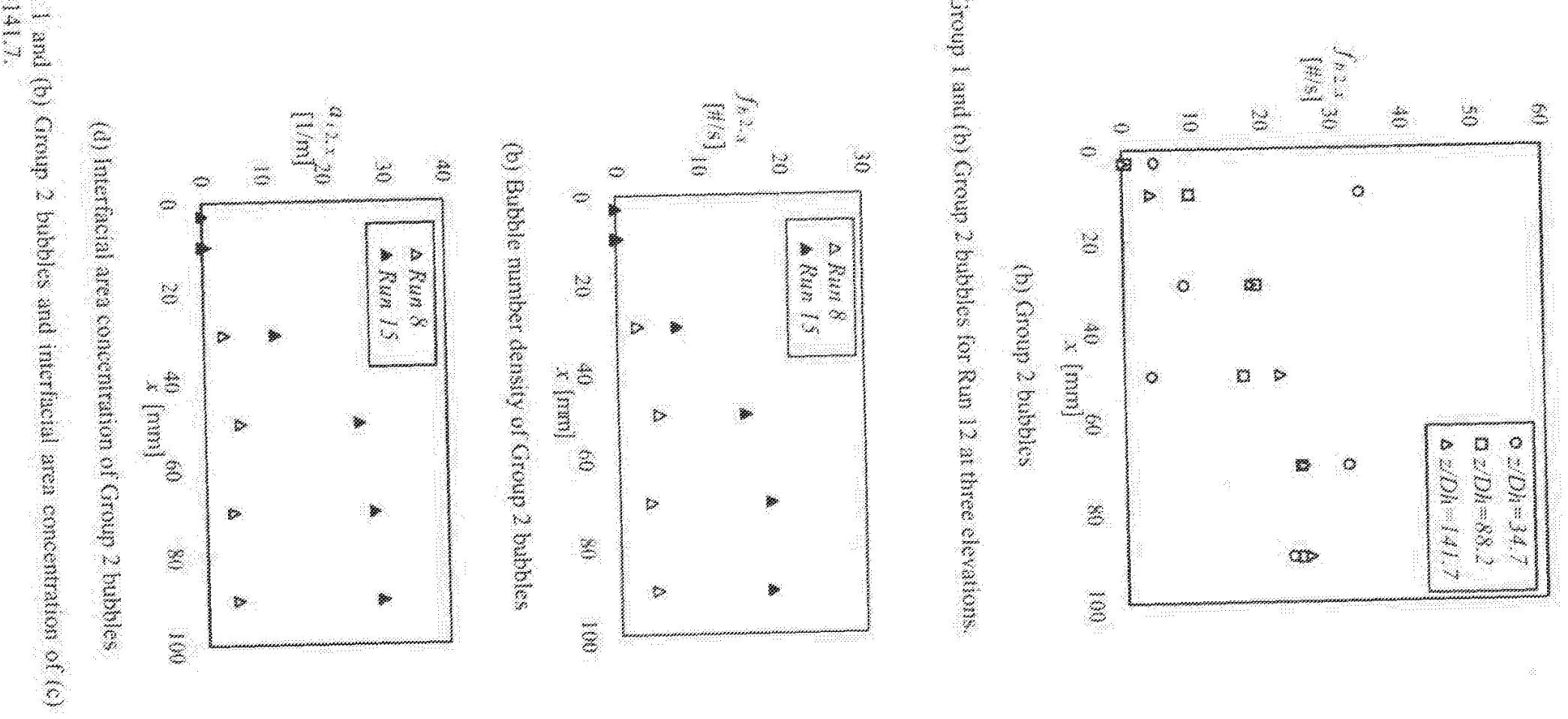


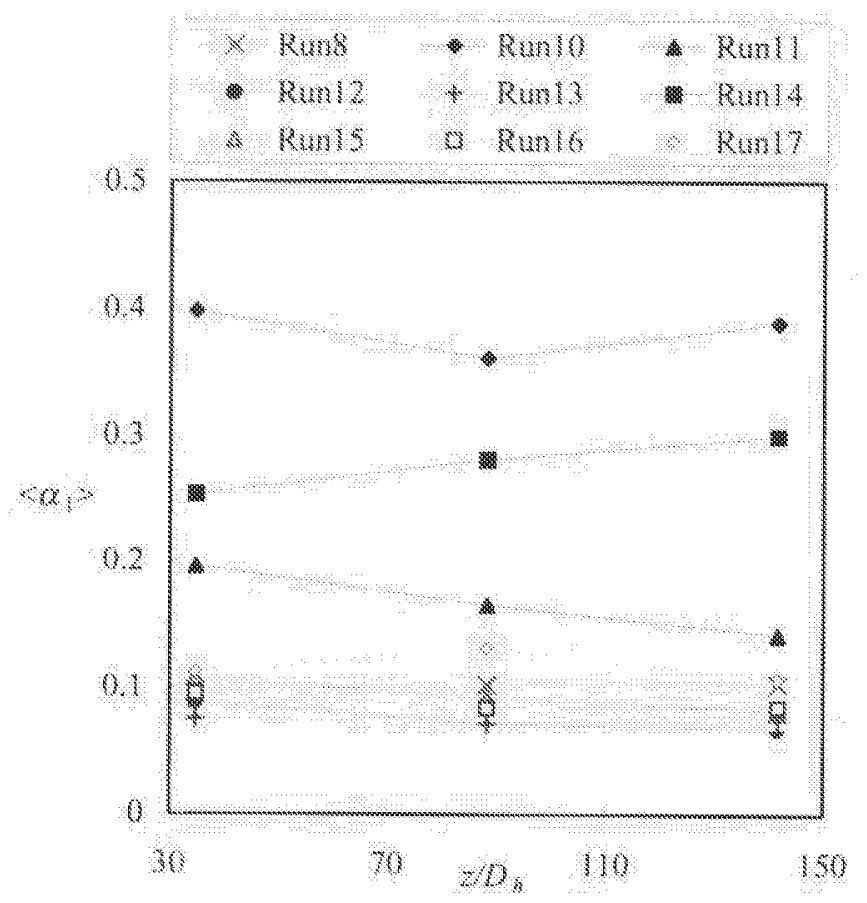

(1) Sowp $)$ bubles

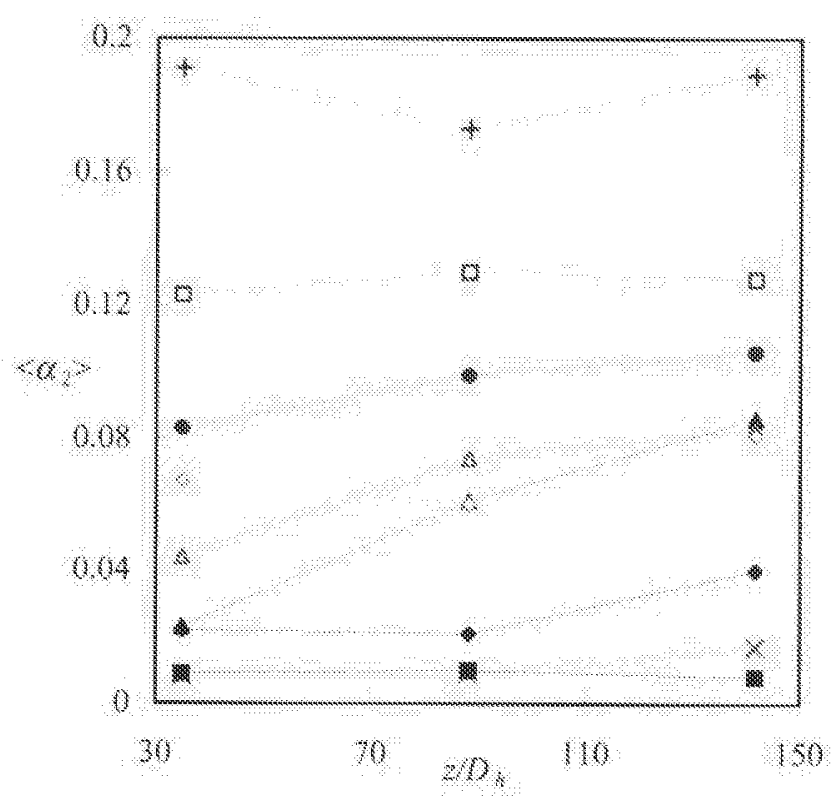

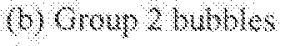

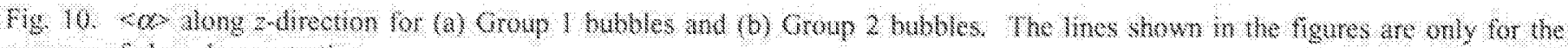

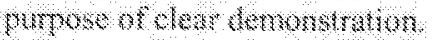

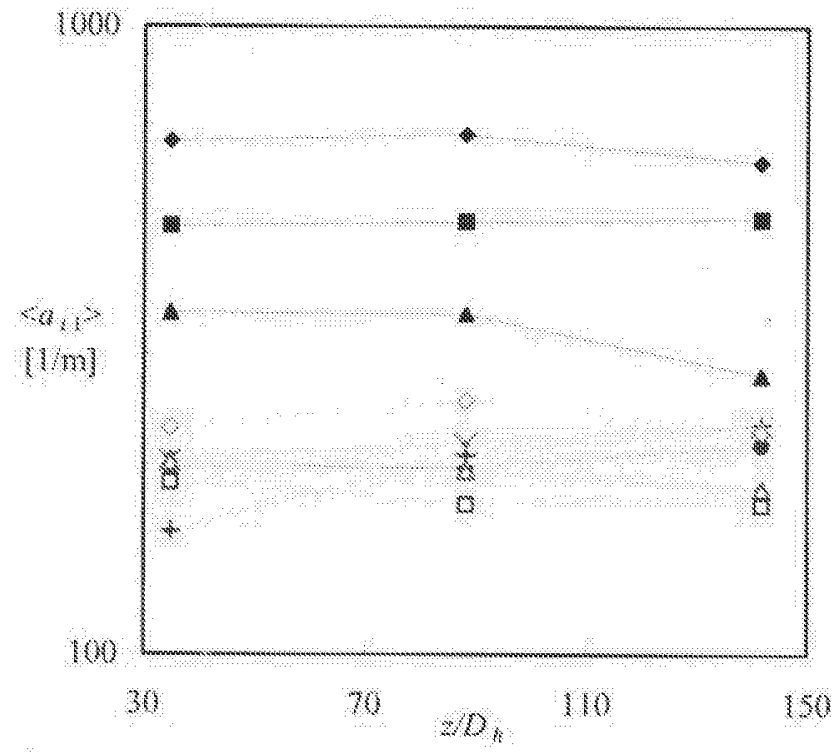

(6) moup 1 abrows

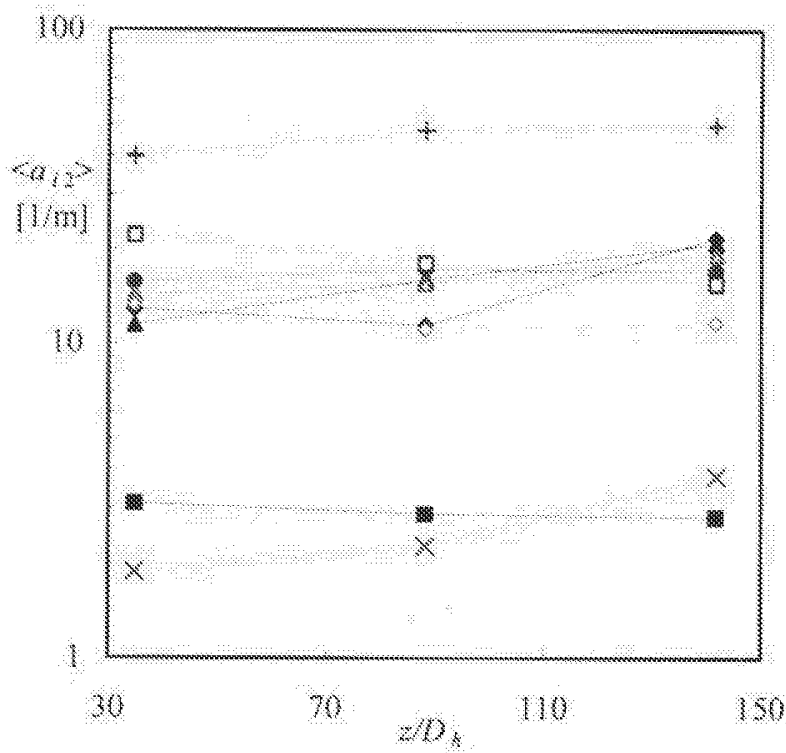

60 mog 2 bures

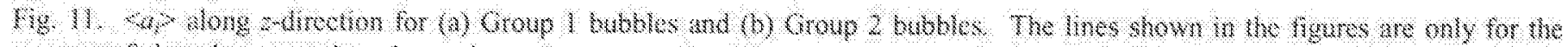

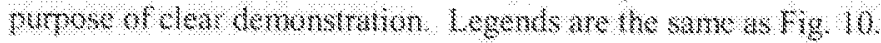




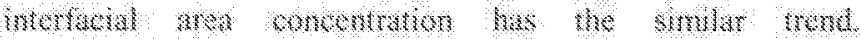

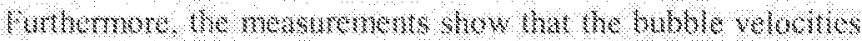

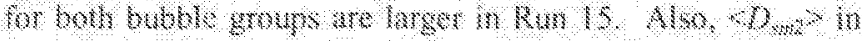

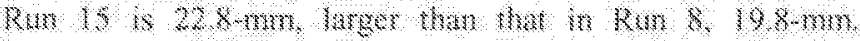

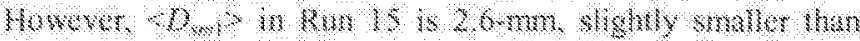

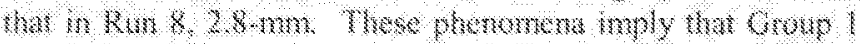

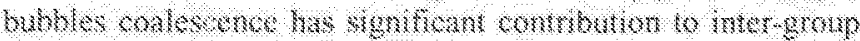

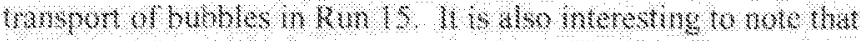

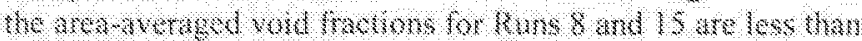

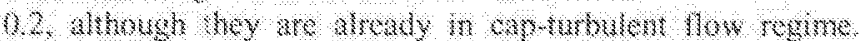

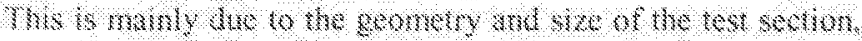

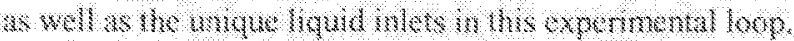

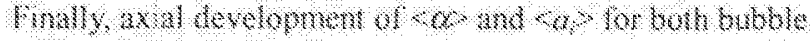

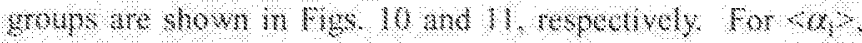

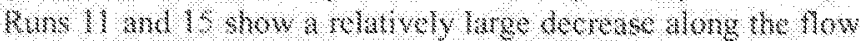

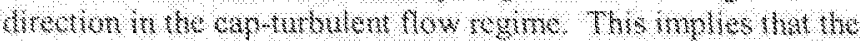

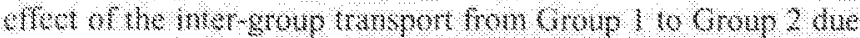

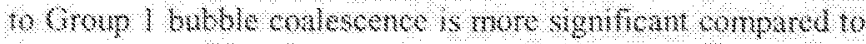

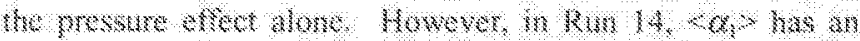

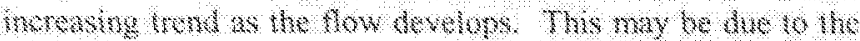

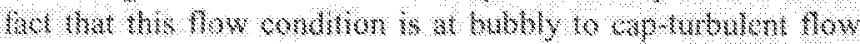

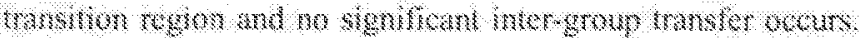

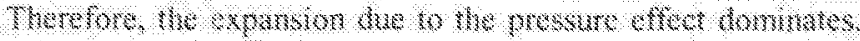

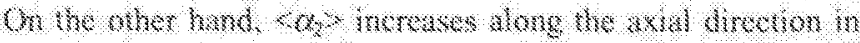

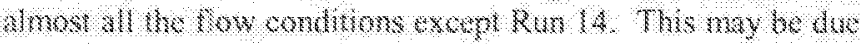
whe inerouse of Groum 2 bxhble velochy

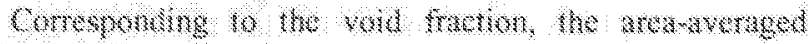

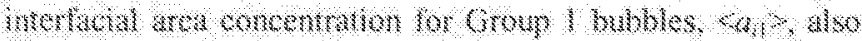

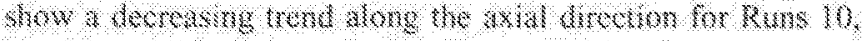

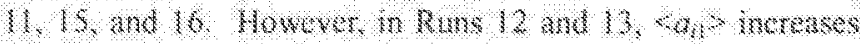

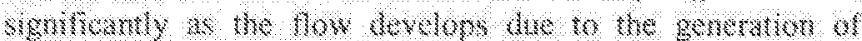
Group 1 bobles from lage buhle dentegration a

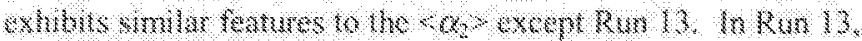

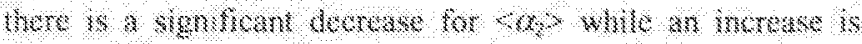
Wherved tor $\mathrm{a}_{\mathrm{s}} \rightarrow$ al Pon 4 Lare inchease of Croup 2 buble

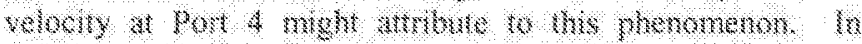

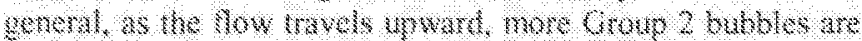

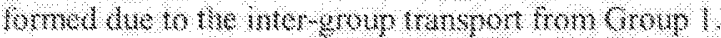

\section{CONCLUS1ONS}

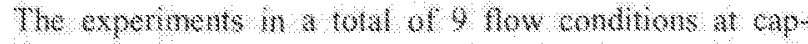

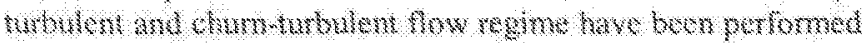

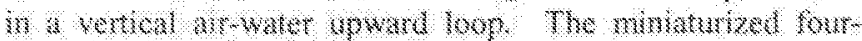

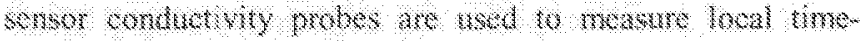
wernged herben wolocty sod hoonom buble number

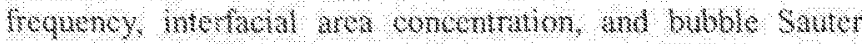

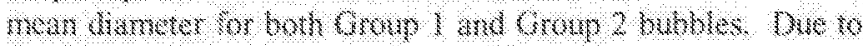

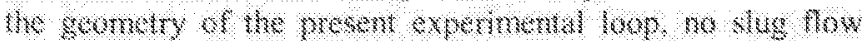

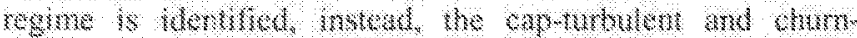
wrbulen how socur at smaker sol thetwo compared to the convertionel romd phes.

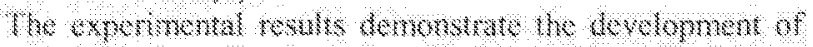

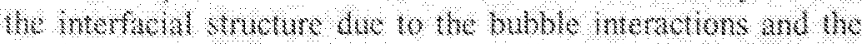

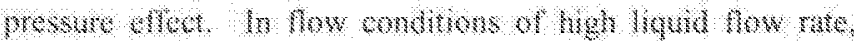

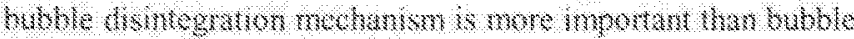

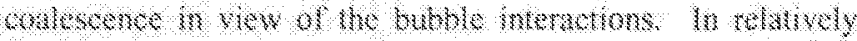

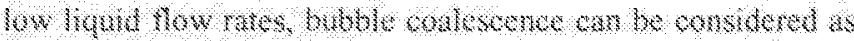

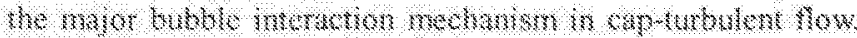

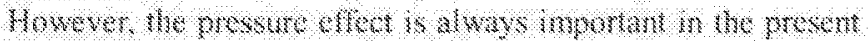

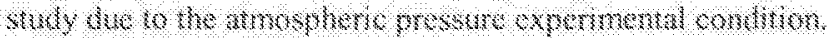

\section{ACKNOW EDGMENTS}

The work was pertomed at Purdue 4 mwersily ander he

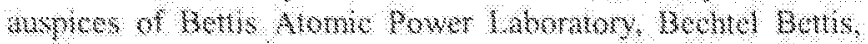
Wh:

\section{RereneNCes}

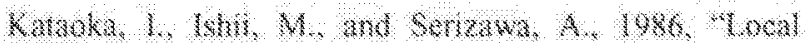
formulaton and Measumements of Merfacta Aroz

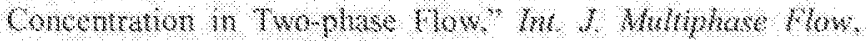
W1 $1,404,11,505.52 \%$

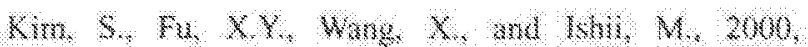

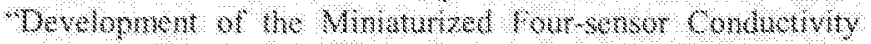

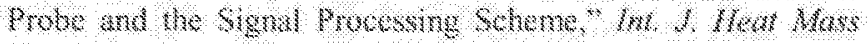

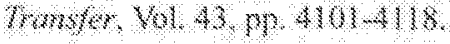

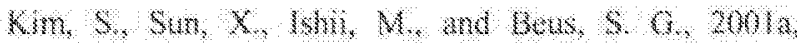

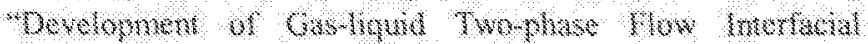

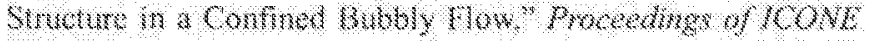
O. Paper No. $160 \mathrm{NE}-121$

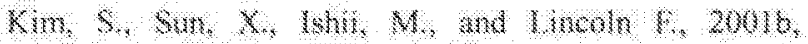

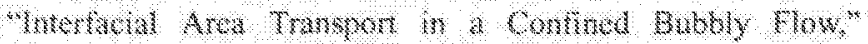

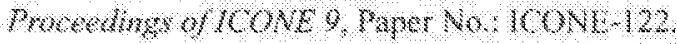

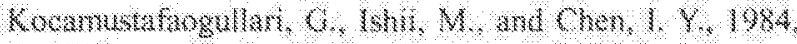

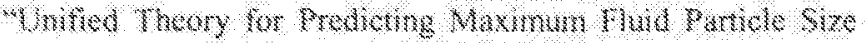

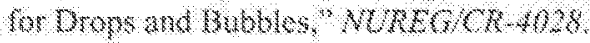

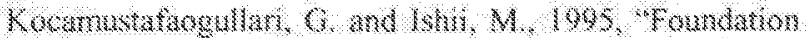

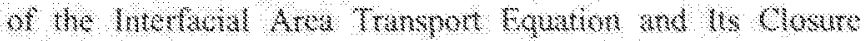

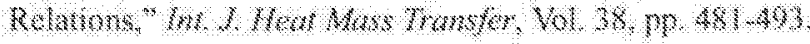

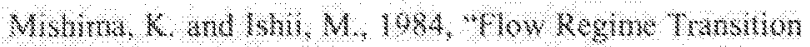

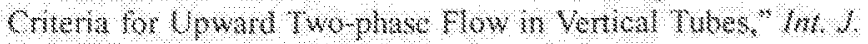
Thow Mow Troms/er, vol. 27, No. 5, bo 723737.

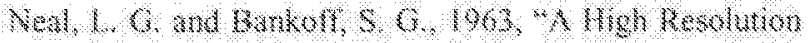
Rersurny Probe for Detemmation or Loed Vor Properties in

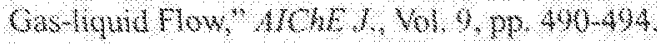

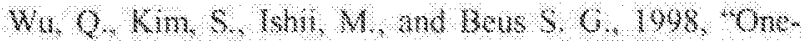

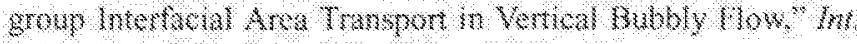

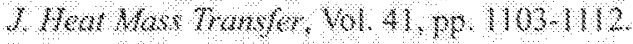

